\title{
Are We There Yet? The Voting Rights Act and Black Representation on City Councils, 1981-2006
}

\author{
Paru R. Shah University of Wisconsin - Milwaukee \\ Melissa J. Marschall Rice University \\ Anirudh V. S. Ruhil Ohio University
}

\begin{abstract}
Sound evidence demonstrating what, if any, role the Voting Rights Act (VRA) has played in the impressive gains minorities have made in local office holding over the last 45 years remains in short supply. The present study is motivated by three crucial questions. First, where are gains in minority office holding most apparent, and how are these gains related to the VRA? Second, while studies have noted gains in black representation over time, the question of how the VRA in particular has contributed to these gains remains unclear. Finally, given claims made by opponents of the 2006 legislation reauthorizing the VRA that it was no longer needed, the question of when the VRA has been most efficacious, and if it continues to be relevant, is also salient. Our findings suggest that the VRA has been and continues to be an important tool in ensuring black descriptive representation, particularly in places with a legacy of racial intimidation and discrimination.
\end{abstract}

T he 2008 election of President Barack Obama was hailed as evidence that America had moved beyond racial politics (Hunt and Wilson 2011). Over two-thirds of Americans saw President Obama's victory either as "the most important advance for blacks in the past 100 years, or among the two or three most important such advances" (Newport for Gallup Politics, November 7, 2008). Certainly, over the past several decades, racial and ethnic minorities have secured elected office at all levels of government. In particular, between 1972 and 2000, the total number of black elected officials in the United States increased by roughly $300 \%$, from 2,264 to 9,040. Latinos too have made inroads, albeit more modestly; the total number of Latino elected officials jumped from 3,063 in 1984 to 5,129 in 2007 - an increase of $67 \%$ (JCPES; NALEO). Regardless of the minority group in question, the vast majority of gains in descriptive representation have occurred in local offices. For example, in 2000, 60\% of all black elected officials and 54\% of Latino elected officials served in mayoral, city council, or schoolboard offices. ${ }^{1}$

Claims of a "postracial" political era in the United States have led many to ask, "Are we there yet?" Since its initial passage in 1965, the Voting Rights Act (VRA) has sought to ensure suffrage-initially for blacks and later for Latinos and other language minority groups-with the goal of increasing the political participation of these groups both as voters and as candidates for elected office. Indeed, hours of heated testimony during the most recent reauthorization of the VRA in 2006 were spent addressing the purported effects and continued need for the VRA (Canon 2008), and although the Act was ultimately extended for another 25 years, the debate continues. For example, in the run-up to the 2012 elections, Georgia, Louisiana, South Carolina, and Virginia challenged the constitutionality of the VRA's preclearance requirement. Further, the U.S. Department of Justice appears set to reverse its initial opposition of the City of Kinston's (North Carolina) proposed shift to nonpartisan elections, and Shelby County's (Alabama) challenge of the VRA's preclearance burden may well reach the U.S. Supreme Court. In short, the continued need for the protections proffered by the VRA remains contested.

Political rhetoric and partisan politicking aside, sound evidence demonstrating what, if any, role the VRA has played in the impressive gains minorities have made in local office-holding over the last 45 years remains in short supply. Specifically, a number of basic

\footnotetext{
${ }^{1}$ An online appendix with supplementary material for this article is available at http://www.journals.cambridge.org/jop. Data and supporting materials necessary to reproduce the numerical results are available from Paru Shah at shahp@uwm.edu.
} 
yet crucial questions remain unanswered. First, where and when have blacks made inroads in crossing the representational hurdle (gaining the first seat on a legislature), where and when have they made inroads towards parity in representation, and is there evidence of VRA effects in these patterns of office holding? Since most research on the VRA has focused only on jurisdictions protected by the VRA's Section 5, at limited points in time we cannot assess how changes in minority representation in these jurisdictions compare to changes in uncovered jurisdictions and if the VRA's Section 5 continues to be relevant. ${ }^{2}$ Second, the question of how Section 5 in particular has contributed to these gains remains unclear. In other words, the mechanism(s) underlying potential causal effects of the VRA on minority office holding remain largely unspecified and untested.

The present study represents the most comprehensive and systematic assessment of these questions to date. Using panel data from both the Joint Center for Political and Economic Studies (JCPES) and the International City/County Manager Association (ICMA), we begin with a brief overview of the electoral protections afforded by the VRA and an empirical profile of office-holding patterns over time and across VRA's Section 5 coverage status, taking into account the relative size of the black polity. Thereafter, we provide existing empirical evidence that ties this component of the VRA to black municipal office holding and review the larger literature that examines black descriptive representation more generally. We then discuss our modeling approach vis-à-vis minority representation on city councils (1981-2006) and place our findings in the larger context of the three questions motivating this study: where, when, and how does the VRA improve the odds of minority success in local elected positions? ${ }^{3}$ Our findings suggest that the VRA has been and continues to be an important tool in ensuring black descriptive representation, particularly in places with a legacy of racial intimidation and discrimination, and that it creates a context that intensifies the

\footnotetext{
${ }^{2}$ Section 5 of the VRA is commonly considered to be the "heart of the Voting Rights Act" (see Tucker 2007).

${ }^{3}$ The VRA is a blanket provision, and as such there is no a priori expectation that the VRA works differently on city councils versus other offices. Indeed, as written, the statute does not apply differentially by type or level of elected office. We choose to focus our analysis on city council representation for two reasons. First, blacks have had much success in attaining this office across the United States, and thus we can more accurately assess the differences between covered and uncovered places. Second, this analysis adds to the discourse on the effects of the VRA on black representation, the majority of which has focused on local offices.
}

effects of voter strength, electoral structures, and council size. Thus, in response to the question, "Are we there yet," our study would say no, but that with the help of the VRA, we are getting closer.

\section{Where and When? The VRA and Minority Electoral Protection}

While the variety of racially discriminatory practices used to disenfranchise black Americans in the preCivil Rights era are well documented and need no recounting here, it is important to understand the consequences of these discriminatory practices. Blacks not only encountered a number of vote-dilution practices (including barriers to registration) and outright voter intimidation, but they also faced significant economic barriers that limited their socioeconomic advancement. While legislation could not directly and instantaneously influence economic advancement, it could dismantle structural barriers to black political participation. This is precisely what the Voting Rights Act set out to do.

The general premise underlying the Voting Rights Act was the democratic principle of equal protections for full political participation of all U.S. citizens. Echoing the language in the 15th Amendment to the Constitution, Section 2 of the VRA is a nationwide and permanent prohibition against voting practices and procedures, including redistricting plans and at-large election systems, poll-worker hiring, and voter registration procedures, that discriminate on the basis of race, color, or membership in a language minority group. In its first review of a case brought under the 1982 amendment, the Supreme Court explained that the "essence of a Section 2 claim is that a certain electoral law, practice, or structure interacts with social and historical conditions to cause an inequality in the opportunities enjoyed by black and white voters to elect their preferred representatives" (Thornburg v. Gingles, 478 U.S. 30, 47 [1986]).

In addition to Section 2, Section 5 of the VRA was enacted to prevent states and political subdivisions with a history of voter discrimination from constantly devising new ways to discriminate once the old ways were abolished by legislation or court decree (United States Commission on Civil Rights 1984). This provision of the law involves a preclearance process whereby any new standard, practice, or procedure with respect to voting in covered jurisdictions must be demonstrated not to "lead to a retrogression in the position of racial minorities with respect to their 
effective exercise of the electoral franchise" (Beer $v$. United States 1976) before it is approved by the Attorney General or the District Court for the District of Columbia (see also Note 1 in the online supporting information). Preclearance applies to all voting changes, whether major or minor, and irrespective of the method by which their adoption is sought (see Note 2 in the supporting information for additional details).

\section{Representational Gains: Has the VRA Achieved What It Was Designed to Do?}

Given that blacks were historically excluded from office holding, it is generally thought that by removing barriers to voter participation and candidacy, the VRA would have its most significant effect on increasing not only black voter participation but also black candidates access and ascension to elected office. At the same time, the conditions that led to the passage of the VRA-voter discrimination and intimidation and vote dilution, as well as restrictions on educational and employment advancement for blacks-meant places covered by Section 5 had considerable ground to make up. Since its passage in 1965, scholars have asked the question: has the VRA achieved what it was designed to do?

Thompson (1982) finds, after careful dissection of turnout, registration, and election data in the South, that while black registration and turnout jumped after 1965, this surge had leveled off by 1980, and both registration and turnout continued to be lower for blacks than for whites. The number of blacks holding elected office in the South also increased over the 1964-80 period. However, as Thompson takes pains to emphasize,

While this increase is striking, it is in some ways misleading ... Not only are there fewer black officeholders than we would expect if racial bias played no significant part in the electoral process, but the rate at which this gap is closing has slowed almost to a standstill. ... Not only do most black elected officials hold municipal offices, the municipalities they represent tend to be villages and small towns that are predominantly black ... [and] the largest group of black mayors in the South is that elected in small towns of less than 1,000 that also have populations over 60 percent black. (1982, 12-19)

If we extend the sweep of history to the present and look at the nation as a whole rather than just Thompson's South, what does the literature show? At face value, it certainly seems that black candidates have increasingly secured elected office (Marschall, Ruhil, and Shah 2010, 110). Distinguishing between places that have never elected a minority representative, those that have elected a single (or token) black and those where blacks represent a "critical mass" in the legislative body, in Figure 1(a) and 1(b), we report longitudinal data for all U.S. cities, first on the number of cities where blacks have overcome the representational hurdle and elected at least one black councilor, and second on the number of black elected councilors, comparing covered and uncovered jurisdictions in each case. ${ }^{4}$ Thus, we can examine more fully where and when gains have been made: is black representation growing across place (i.e., are the number of places with at least one black council member increasing), or are the cities that have crossed the hurdle gaining more blacks on the council, moving perhaps towards representational parity? While this descriptive analysis does not allow us to draw casual inferences about the effects of the VRA, it does provide important empirical evidence regarding covariation and temporal order. Furthermore, it provides more extensive evidence on the relationship between the VRA and black office holding by considering two distinctive and largely overlooked dimensions of representation.

The data in Figure 1(a) and 1(b) show that whereas the total number of black elected councilors has increased over time regardless of coverage (upper panel), there is more variation in the number of jurisdictions with black council representation depending on Section 5 coverage (lower panel). Specifically, between 1981 and 2001, the number of covered cities with at least one black elected councilor increased from 552 to 1,004, marking a nearly $200 \%$ change; however, the number of uncovered cities with at least one black councilor increased less rapidly, then dropped precipitously in 2001. Figure 1(a) and 1(b) also reveal that the two trend lines crossed in 1991 and that since this time, more cities covered by Section 5 have elected at least one black councilor than have exempted cities, and the total number of black elected councilors has been greater in covered jurisdictions. Moreover, only in covered jurisdictions do we see consistent gains both in total number of black elected councilors and in total number of places with black representation.

In Figure 1(c) through 1(e) we report data that allows us to compare trends in the percentage of cities where blacks have and have not overcome the representational hurdle to those where blacks have

${ }^{4}$ Data for Figure 1(a) and 1(b) comes from the Joint Center for Political and Economic Studies Roster of Black Elected Officials and thus constitutes the full population of places in the United States with black representation on city councils for any particular year. 


\section{FIgURE 1 Distribution of Black Councilors (by year and Section 5 coverage)}

(a)

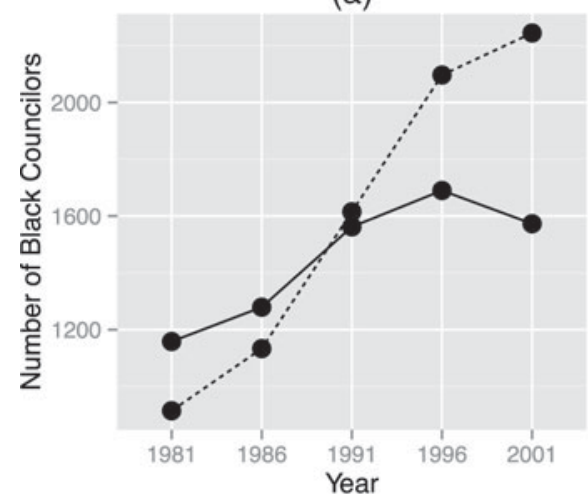

(c)
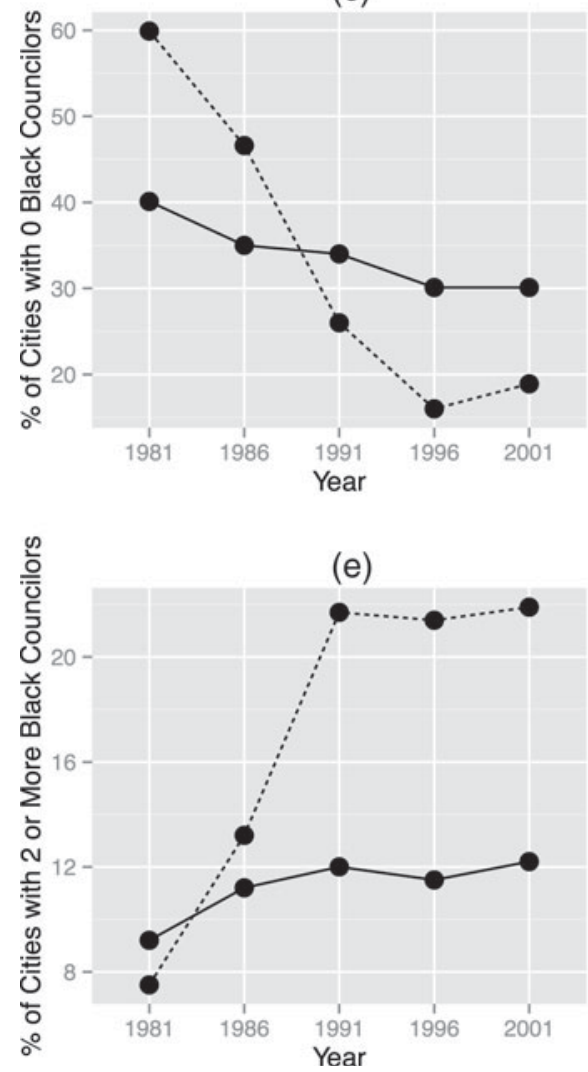

VRA

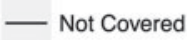

..... Covered

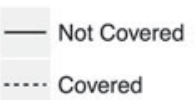

- Not Covered

..... Covered

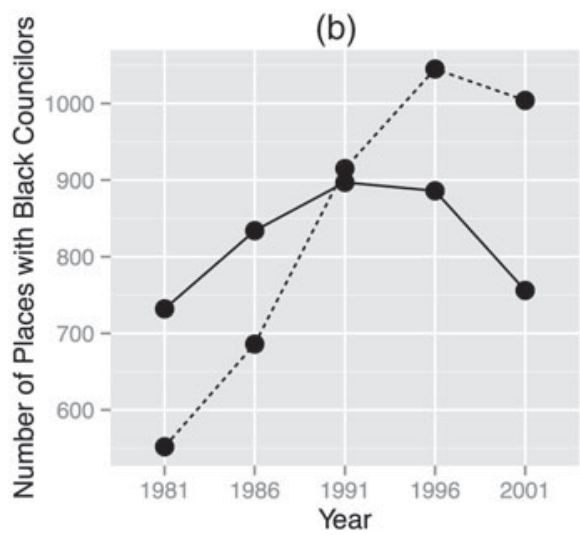

VRA

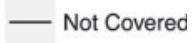

-.... Covered

(d)

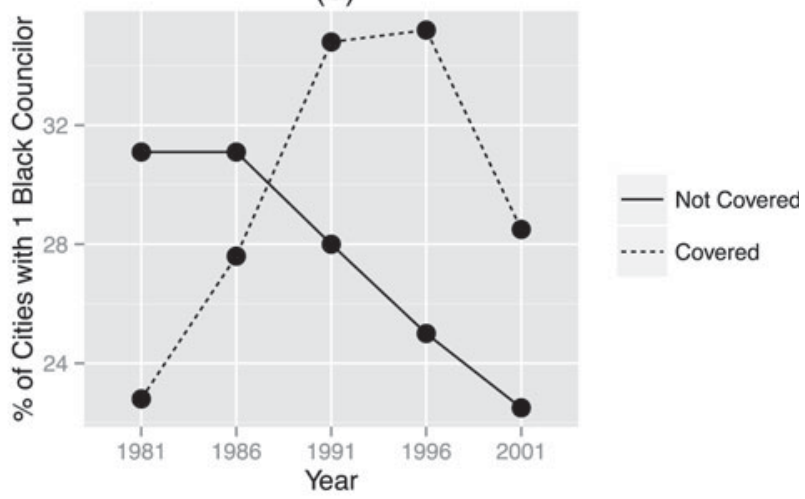

Note: Subfigures (a) and (b) display the total number of councilors at the indicated time period by Section 5 coverage. Subfigures (c) through (e) report the percentage of cities with zero and one, two, or more black councilors between 1981 and 2001 by Section 5 coverage. Data for Figure 1 comes from the Joint Center for Political and Economic Studies Roster of Black Elected Officials and thus constitutes the full population of places in the United States with black representation on city councils for any particular year.

made significant inroads in representation, occupying two or more seats. These data underscore a markedly different pattern across covered and uncovered jurisdictions. For one, while the percentage of cities with no black councilor was considerably smaller in uncovered versus covered areas in 1981 (40\% vs. 60\%), there is a steady and sharp decline in covered jurisdictions, particularly between 1981 and 1991, that is not matched by uncovered jurisdiction. Indeed, by 1991 only $26 \%$ of covered cities had failed to elect a black council member, whereas in uncovered jurisdictions, $34 \%$ of cities still lacked a black councilor. Second, increases in black council representation in uncovered jurisdictions appear to occur primarily in cities where blacks had already crossed the representational hurdle, whereas in covered cities, we see an 
increase both in the number of cities realizing their first black representative and in the number of cities where blacks were expanding their representation on the council. Finally, gains in both access and additional seats are considerably stronger in covered versus uncovered jurisdictions, such that by 2001 , the percentage of covered cities with one and two or more black councilors was greater than that percentage of uncovered cities.

While the data presented thus far show greater gains in representation in covered jurisdictions in the 1990s, they do not tell us where these gains were greatest. In other words, did all cities in covered jurisdiction experience similar gains over time, or were these gains concentrated in certain types of cities, such as majority-black cities as Thompson (1982) finds? To examine these "where" questions, we disaggregate the data reported in Figure 1(a)-1(e) by black population size. As the data in Figure 2 reveal, there are sharp differences across majority black and minority black cities in covered versus uncovered jurisdictions. ${ }^{5}$

First, black councilors are most likely to be found in majority-black places (both covered and uncovered), and this has remained true throughout the 20-year period. Moreover, the difference between covered and uncovered majority black places remained negligible until the late 1990s, at which point we see a widening gap. Second, although we see steady increases in black council representation across black population levels between 1981 and 2001, the rate of growth is consistently steeper in covered cities. Much like the aggregate data presented in Figure 1(a)-1(e), here we find a similar stagnation in growth over time for uncovered places, resulting in much flatter slopes. In contrast, growth rates in covered places range from $136 \%$ to $235 \%$, with largest gains occurring in places with modest black populations (0-20\%).

Together, these patterns suggest that the answers to questions of where and when black council representation has changed vary according to both VRA coverage and the size of the black population. In places with majority black populations, coverage provides the least assistance. On the other hand, we find the steepest gains in covered cities where the black population is less than $20 \%$, suggesting the VRA may be most important in places where black population size cannot, by itself, ensure black representation.

\footnotetext{
${ }^{5}$ Majority black cities are defined simply as those with blacks comprising $51 \%$ or more of the voting-age population. Note also that by explicitly accounting for black population size, we negate the argument that black representation differs in covered versus uncovered jurisdictions because blacks are less prevalent in covered jurisdictions.
}

\section{How? Explaining Black Gains in Council Representation}

The over-time data reported in the previous section demonstrate quite clearly the marked distinctions in the likelihood of both crossing the hurdle of representation and expanding this representation according to Section 5 coverage. The essential question here, though, is what role does the VRA play in the preceding patterns? The vast majority of research attempting to answer this question has focused on the indirect effect of the VRA on black representation. In particular, building upon the large body of research demonstrating an association between single-member districts and minority representation (Bullock and MacManus 1993; Engstrom and McDonald 1981; Karnig and Welch 1982; Marschall, Ruhil and Shah 2010; Meier and England 1984; Trounstine and Valdini 2008), scholars have long hypothesized that electoral changes in covered jurisdictions would lead to increases in minority representation. Specifically, single-member districts (SMD) are argued to concentrate blacks into compact electoral districts, reducing their reliance upon other groups in the electorate and increasing their capacity to elect black candidates to legislative office. In contrast, at-large (AL) systems require all candidates to compete city wide, and the omnipresent threat of racial bloc voting requires larger, typically majority, black voting-age populations, or more intensive reliance on cross-over voters if minority candidates are to win.

Testing this hypothesis, however, requires a sufficiently large number of jurisdictions to actually change from AL systems to SMD or Mixed systems. Indeed, in the years following passage of the VRA, a number of cases scrutinized AL systems (see, e.g., White v. Regester 1973; City of Mobile v. Bolden 1980; Thornburg v. Gingles 1986, and each of these developments made it easier for local jurisdictions to successfully challenge their AL systems (see also Note 3 in The supporting information). Davidson and Korbel (1981) documented these changes in the case of Texas. They found that while virtually all Texas city council and school board members were elected at-large in 1970, by 1980 about a third of all urban voters elected at least some of their council from single-member districts. According to Davidson and Korbel, though changes from AL to SMD electoral systems came about largely through federal court intervention, even when jurisdictions "voluntarily" changed their election methods, litigation was usually either in progress or threatened. 
FIGURE 2 Distribution of Black Councilors (by year, Section 5 coverage, and Black VAP \%)
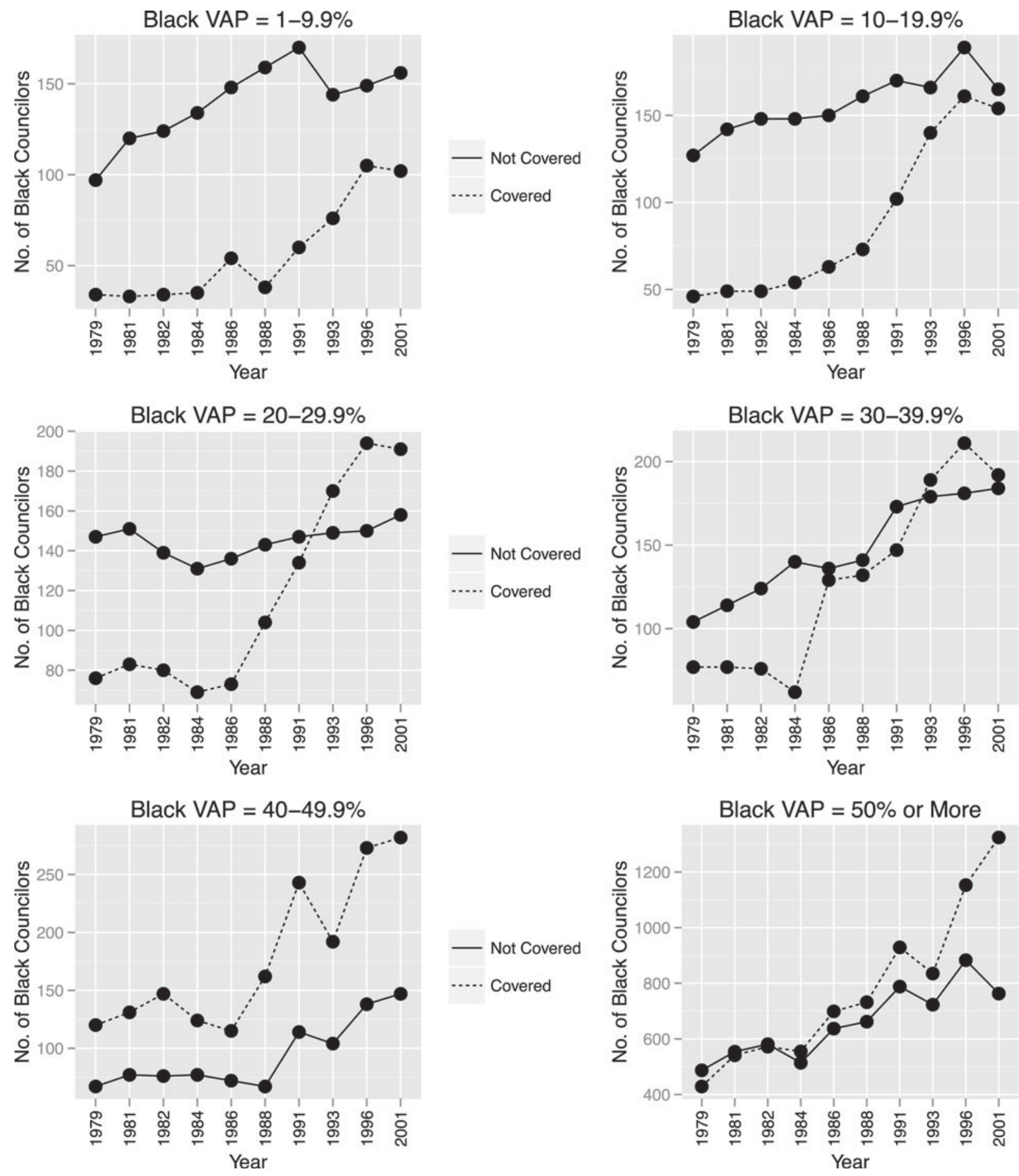

Note: Total number of black councilors is displayed by percentage of the city's black voting age population (VAP) and Section 5 coverage. Data for Figure 2 comes from the Joint Center for Political and Economic Studies Roster of Black Elected Officials and thus constitutes the full population of places in the United States with black representation on city councils for any particular year.

Davidson and Korbel's study (1981) found increases in the proportion of black and Latino office holders in the 41 Texas jurisdictions identified as having switched from AL to SMD or Mixed systems between 1970 and 1979. However, their study lacked an appropriate control group, and thus they were unable to rule out the possibility that similar increases in minority office holding also occurred in cities that 
had not changed their electoral arrangements. ${ }^{6}$ Noting this limitation, Mundt and Heilig (1982) conducted a longitudinal analysis of 209 southern cities and compared cities that changed from AL to either SMD or Mixed systems to those that retained their electoral structure. They found sharper increases in black council representation in the cities that changed their electoral structures. However, Mundt and Heilig did not control for the effects of black population size, and thus their study left open the possibility that the relationship between electoral change and gains in black representation was spurious - that the increases flowed from larger increases in black voting-age populations rather than changed structure per se.

To address this shortcoming, Grofman and Davidson (1994) compared black representation on city councils from the early 1970 s to $1989 / 1990$ for a set of cities in eight southern states that shifted from AL to Mixed or SMD elections to a set of cities that retained AL arrangements throughout this period. ${ }^{7}$ Controlling for black population size, they found stronger gains in black representation in cities that abandoned AL systems compared to those that did not, though cities retaining AL arrangements also registered gains. Another study by Sass and Pittman (2000) reanalyzed Grofman and Davidson data, adding two additional time points (1991 and 1996). ${ }^{8}$ They concluded that while a change to SMD elections initially exerted a large impact on black representation, this effect diminished between 1981 and 1991 and then increased slightly between 1991 and 1996. On the other hand, the ability of blacks to win local AL elections increased steadily between 1970 and 1990 before leveling off.

In total, these studies demonstrated that when municipalities in covered or southern jurisdictions switched electoral arrangements, they registered gains in black council representation. However, the exclusive focus on the South generally or on areas covered by

\footnotetext{
${ }^{6}$ Of the 41 jurisdictions identified as having switched from AL to SMD or Mixed systems between 1970 and 1979, Davidson and Korbel (1981) find the proportion of black officeholders increased from 6 to $17 \%$, and the proportion of Latino officeholders increased from 5 to $12 \%$.

${ }^{7}$ The sample included 1,060 cities, though more than two-thirds (724) were in one state (North Carolina). Documenting changes in electoral systems is a cumbersome task that is rarely, if ever, undertaken, and as such, Davidson and Korbel (1981) and Grofman and Davidson (1994) deserve credit for their noteworthy efforts.

${ }^{8}$ These data were compiled by ICMA via their Form of Government Surveys.
}

Section 5 in particular meant that these studies could not rule out the possibility that similar increases in black council representation occurred in noncovered and/or nonsouthern jurisdictions over this time period. Sass and Mehay (1995) addressed this problem by examining a constant sample of southern and nonsouthern cities drawn from International City/Council Management Associations (ICMA) surveys in 1981 and 1991. Consistent with the previous research, their crosssectional analysis concluded that district elections aided black candidates and that these effects were greater in states covered by the VRA. Their analysis also revealed that district elections were associated with sharper gains in representation in the southern versus nonsouthern localities prior to the 1982 amendments, but that in the following decade, blacks made more steady progress in winning AL seats, substantially narrowing the representational gap between AL and district systems particularly in southern cities.

To sum, the research to date that has examined the effect of the VRA on black representation has concluded that changes to SMD in covered jurisdictions leads to gains in black office holding. What is still unknown, however, is does the VRA work in conjunction with other factors to yield these gains? Moreover, how do these mechanisms manifest in the extent of representation as opposed to electing a single representative? Do they matter differently for cities getting over the hurdle versus those moving towards representational parity? In the following section, we examine the role that other key variables might play in explaining black descriptive representation and identify how the VRA could operate directly on black council representation by conditioning the effect of these factors.

\section{The Direct Effect of the VRA}

As Parker outlines in his examination of Mississippi after the passage of the VRA: "In large part, the white supremacy politics of the white majority shaped post-1965 black politics" (1990, 90). Thus, despite impressive gains in voter registration and the banning of voter dilution practices in Section 5 covered places, the passage of the VRA did not immediately result in a commensurate increase in the number of black elected officials. Indeed, even in black majority districts, black candidates were consistently losing to white candidates (see, e.g., Salamon and Van Evera 1973). Moreover, a number of monographs have detailed the difficulties of getting blacks to the polls early on, as black voters were still intimidated by white poll workers, and black candidates still faced 
discrimination in terms of candidacy qualifications (Andrews 2004; Morrison 1987). To be sure, these contextual effects help explain the lags in representation illustrated in Figures 1-2 and suggest that, at least early on, the direct effect of the VRA was likely negative.

Yet, Figures 1-2 also clearly demonstrates that over time, gains in covered jurisdictions outpaced those in uncovered places. How can this be explained? One possibility is that in addition to the gradual yet sustained effects that changes in electoral structures had on black council representation in covered jurisdictions, the VRA operated directly on black representation by conditioning the effects of other factors known to increase the number of legislative seats held by blacks.

First, a long line of research has concluded that racialized voting has played a pivotal role in the election of blacks and other minorities to political office. Thus, as the size of the black population in a particular city or district increases, the likelihood of black representation increases (see Marschall, Ruhil and Shah 2010 for a comprehensive review). We hypothesize that these effects were greater in covered jurisdiction for a number of reasons. For one, an explicit goal of the civil rights movement centered on black enfranchisement and political participation in the South with civil rights groups working relentlessly to register, mobilize, and empower black voters throughout this period. Research by McAdam (1982) finds that activities of black churches, historically black colleges (HBCUs), and the NAACP created communication networks and developed leaders that ultimately led to a "campaign for change." Andrews (1997) examined how the presence and size of Freedom Summer volunteers and NAACP members in the mid-1960s impacted black electoral politics in Mississippi between 1967 and 1984. He finds a positive and significant relationship between these "social movement" indicators and both number of black candidates and number of black elected officials at the county level and concludes from this that the development and continued presence of resistance organizations post1965 were important for creating the electoral infrastructure that led to black empowerment at the local level. This infrastructure and the fact that blacks in the South were politically motivated and increasingly activated meant that they could more effectively translate their votes into legislative seats.

Second, much of the research on black descriptive representation has focused on the effects of governing institutions. As we noted above, the scholarship on the positive effects of SMDs on black council representa- tion is large and rather convincing. Another, albeit smaller, line of research has focused on the size of the legislative body as an important indicator of electoral opportunity for minorities. For example, Jones (1976) finds that larger councils provide greater equity in black representation, particularly in cities where council members are elected at-large, and particularly in the South. Jones attirbuted this finding to Southern voters and candidates fighting against the prevailing institutional racism embodied by smaller councils, which increased competition for seats and reduced the electoral chances of black candidates. A number of scholars have also argued that larger councils make black power more "palatable" to white voters (Alozie and Manganaro 1993; Karnig and Welch 1980; Taebel 1978), increasing whites' willingness to share power, as they lessen the prestige of membership and make each "share" of power smaller. Tying this research together with the scholarship detailed above on SMDs, we suspect that cities with SMDs and larger councils would be more likely to elect black council members, particularly when covered by Section 5 (ceteris paribus). That is, the increased political opportunity afforded by SMD and larger councils will be realized to a greater degree in cities covered by Section 5 .

Third, a number of scholars have pointed to the positive effects of black resources in determining black representation, including helping African Americans develop strategies to achieve their political goals, mobilize more minority voters (Browning Marshall, and Tabb 1984), develop the leadership potential to sustain interest-group activities (Giles and Evans 1985,51 ), and increase the supply of qualified minority candidates (Meier and Stewart 1991). However, we believe these positive effects would be mitigated in covered jurisdictions. In particular, research has documented the use of economic coercion in intimidating blacks both before and after passage of the VRA. In the rural and small-town settings of many places in the Deep South, virtually all blacks were dependent to some extent on local whites for their income. A study commissioned by the U.S. Civil Rights Commission in 1964 to determine why so few black teachers registered to vote in Mississippi discovered that "fear of loss of a job" was the most common response. On the basis of this and other evidence, the Civil Rights Commission concluded "the economic dependence of Negroes in the South inhibits them from engaging freely in political activity and voting for candidates of their choice" $(1968,127)$. In their county-level analysis of Mississippi in 1971, Salamon and Van Evera (1973) conclude this economic intimidation explains the vast majority of variation in black political 
participation (69\%), as opposed to discrimination and apathy. Thus, in covered cities where the black population had more resources, it would likely be tied to dependence on whites, and thus we would expect them to be less willing and able to employ those resources toward their own political goals.

Last is the question of white "crossover" voting, particularly in jurisdictions where African Americans do not comprise a majority of the population (Bullock and Campbell 1984; Liu 2001). Scholars have examined when and where black candidates will attempt to form coalitions with liberal or more highly educated white voters, and the findings are mixed. For example, in their study of 10 California cities in the 1970s, Browning, Marshall, and Tabb (1984) conclude that liberal white voters played key part in blacks attaining political office. On the other hand, Marschall, Ruhil, and Shah (2010) find that the percentage of liberal white voters (measured as the percentages of white residents with at least a Bachelors degree) not only decreases the electoral prospects of black candidates but also has stronger effects in locations with both a history of past black political incorporation and large black populations. They argue their findings are more consistent with traditional explanations that focus on prejudice and racial threat rather than those that emphasize intergroup cooperation or change in racial attitudes. Given historical race relations in the South, we too are skeptical of the prevalence of crossover voting, particularly in the early decades following passage of the Voting Right Act. Instead, we suspect that the concentration of white liberals in covered places would be only weakly or perhaps unrelated to black office holding in cities covered by Section 5 .

To sum, based on the literature that looks more broadly at the factors that influence black office holding, we have identified several ways in which the VRA might have conditioned the effects of these explanatory factors and thereby operated more directly on black representation on city councils. In addition to testing these relationships, our empirical analyses will also investigate whether and how the effects of the VRA might vary according to how representation is conceptualized and measured. In other words, does the VRA condition the effects of black population size similarly in places overcoming the representational hurdle as opposed to those moving towards representational parity? As our study is the first to examine this specific question, a priori we make no definitive hypotheses as to which variables will matter at the first or second stage of representation.

\section{Data, Analytic Strategy, and Model}

To empirically evaluate the questions of where, when, and how the VRA could have contributed to gains in black council representation, we constructed a panel dataset from the International City/County Management Associations (ICMA) Form of Government (FOG) surveys, administered every five years $(1981,1986,1991,1996,2001$, and 2006). ${ }^{9}$ We supplemented information on the governing structures, electoral systems in use, and the race/ethnicity of councilors from the ICMA surveys with socioeconomic and demographic data from the decennial Census of Population and Housing (1980, $1990,2000,2010)$, interpolated to correspond to the survey year. Section 5 coverage comes from the U.S. Department of Justice Civil Rights Division.

Given our interest in examining not only whether or not cities had black council members in office, but also how many, our analytic strategy must be able to capture these facets of the representation process. Thus, we employ the broader conceptualization of council representation advanced by Marschall, Ruhil, and Shah (2010) and estimate a two-stage hurdle model that permits us to differentiate between the effects of Section 5 coverage on the probability of any black representation and the expected number of seats held by black council members. The probability function of a hurdle model can be written as

$$
f(y)= \begin{cases}g(0), & \text { if } y=0 \\ \frac{1-g(0)}{1-h(0)} h(y), & \text { if } y \geq 1\end{cases}
$$

where the zeros (no black councilor) and the positive counts (one or more black councilors) are determined by the probability $g(0)$ and the truncated probability function $h(y \mid y>0)=(h(y)) / 1-h(0)$, respectively. Typically, $g(0)$ is estimated via probit or logit and $h(y \mid y>0)$ is estimated via zero-truncated Poisson (see also Note 4 in the supporting information).

Dependent variables. Black council representation includes two measures. For the first, Incidence of Representation, we code those places with at least one

\footnotetext{
${ }^{9}$ The resulting dataset is an unbalanced panel with 4,610 (1981), 4,582 (1986), 4,900 (1991), 4,493 (1996), 4,173 (2001), and 4,302 (2006) cities in the respective panel-years, and a subset $-1,897$ cities - appear in every panel-year. Ideally, we would have data spanning some time before 1965 and immediately after to be able to isolate the effects of the VRA legislation alone, but no such large data set exists. Given the reauthorizations of the VRA over the last 47 years, however, we would argue that our dataset still provides a good test of the effects of the legislation and the impact of its legacy.
} 
black councilor as 1 and those without black council representation as 0 . The second measure, Extent of Representation, is coded as the number of black councilors in the legislative body. Data for both measures come from the ICMA surveys.

Independent variables. Our primary independent variable of interest is whether a jurisdiction is covered under Section 5 of the Voting Rights Act $(1=$ Covered $)$ or not $(0=$ Uncovered $) .{ }^{10}$ In the baseline model, this dummy variable allows us to test for the independent effects of Section 5 coverage on black council representation, controlling for the full set of covariates identified in the literature. In the conditional model, we explore the differences between covered versus uncovered jurisdictions by interacting Section 5 with a set of variables that allow us to operationalize the various mechanisms discussed in the previous section.

The first of these is black voting strength, which we measure as the black voting-age population in the municipality (Black VAP). ${ }^{11}$ Second, we include two measures of electoral arrangements: the Size of the City Council and the electoral institutions. The latter is coded as a series of dummy variables $(0=$ yes, $1=$ no): pure Single-Member District $(S M D)$, pure At-large $(A L)$, or Mixed. At-large is the excluded comparison group in all models. Beyond these variables, we also include a measure for black resources, percent Black Employment. Finally, we operationalize the possibility of crossover voting with a variable that measures the percent of the non-Hispanic White population with at least a bachelor's degree (White with Bachelors Degree).

In addition to this set of explanatory variables that help us test the "how" question regarding the relationship between the VRA and black council representation, our models also include year a set of time dummies that allow us to investigate the "when" question. These dummy variables correspond to the ICMA survey years:1981, 1986, 1991, 1996, 2001, and 2006 (1981 is the excluded category). Finally, we include a set of control variables as well. Specifically, we control for city size with a variable that measures the natural logarithm of the population size of the city (City Size, Logged). Last, to control for the racial context of the city, we include a dummy variable that measures Predominantly White Cities ( $=1$ if the Non-Hispanic White population greater than $60 \%$;

\footnotetext{
${ }^{10}$ As coverage changed over time with subsequent reauthorizations, our measure is dynamic and changes to match coverage of the particular year in question.

${ }^{11}$ We restrict our analysis to those places with greater than $1 \%$ black VAP.
}

0 otherwise). Summary statistics of the resulting datasets are available in the online supporting information, Table A.

\section{Empirical Analysis and Findings}

Table 1 provides the results from two hurdle models-a baseline model to be used as a point of reference and the full interactive model. We begin with the question of "where", and the baseline model allows us to test whether Section 5 has a direct and independent effect on black council representation when controlling for the full complement of covariates and whether this effect varies according to the stage of representation. As the results in first two columns of Table 1 reveal: ceteris paribus, Section 5 coverage provides an important springboard of getting over the initial hurdle of no representation. Substantively, the probability of a black council member is .56 in a covered jurisdiction, compared to .32 in an uncovered city in the first stage. ${ }^{12}$ On the contrary, the results from the baseline model do not support an independent effect of Section 5 coverage on the extent of black representation. In other words, Section 5 increases the likelihood that cities have a single black council member but is not associated with expanding black council representation beyond this single member.

We turn to the model in which Section 5 is interacted with key independent variables to assess the questions of when and how the context of coverage matters for black council representation. Columns 3 and 4 of Table 1 report the results from the two-stage, conditional models. Looking first at the question of when Section 5 matters, we focus on the coefficients on the last set of interaction terms (Section $5{ }^{*}$ time). What we find is a consistent effect in the second stage but no effect in the first stage. These estimates suggest a significant gain in the number of seats held by black council members in covered jurisdictions over time. On the other hand, what we also find, over time, is that cities not covered by Section 5 that have crossed the hurdle of representation have remained more stagnant over time, unable to expand beyond a single black council member (see Figure A in the supporting information). These predictions corroborate descriptive evidence provided in Figure 2 and suggest that the VRA was particularly instrumental in ensuring

\footnotetext{
${ }^{12}$ All predicted probabilities are calculated with margins in Stata 12. Predicted probabilities are calculated at the mean values for continuous variables, the modal value for binary variables, and year $=2001$ (unless otherwise noted).
} 
TAble 1 Models

\begin{tabular}{|c|c|c|c|c|}
\hline & \multicolumn{2}{|c|}{ Baseline Model } & \multicolumn{2}{|c|}{ Full Model } \\
\hline & Logit & $\begin{array}{c}\text { Zero-Truncated } \\
\text { Poisson }\end{array}$ & Logit & $\begin{array}{c}\text { Zero-Truncated } \\
\text { Poisson }\end{array}$ \\
\hline & beta/standard error & $\begin{array}{c}\text { beta/standard } \\
\text { error }\end{array}$ & $\begin{array}{c}\text { beta/standard } \\
\text { error }\end{array}$ & $\begin{array}{c}\text { beta/standard } \\
\text { error }\end{array}$ \\
\hline Section 5 & $\begin{array}{l}0.315^{\star * \star} \\
(0.055)\end{array}$ & $\begin{array}{c}0.055 \\
(0.041)\end{array}$ & $\begin{array}{c}0.205 \\
(0.363)\end{array}$ & $\begin{array}{l}-0.890^{\star} \\
(0.364)\end{array}$ \\
\hline Black VAP & $\begin{array}{l}11.705^{\star * \star} \\
(0.285)\end{array}$ & $\begin{array}{l}3.590^{\star * *} \\
(0.110)\end{array}$ & $\begin{array}{l}12.458^{\star * *} \\
(0.379)\end{array}$ & $\begin{array}{l}3.608^{\star * *} \\
(0.129)\end{array}$ \\
\hline SMD & $\begin{array}{l}0.614^{\star * *} \\
(0.073)\end{array}$ & $\begin{array}{l}0.341^{\star * *} \\
(0.048)\end{array}$ & $\begin{array}{l}0.349^{\star * *} \\
(0.089)\end{array}$ & $\begin{array}{l}0.298^{* * *} \\
(0.068)\end{array}$ \\
\hline Mixed & $\begin{array}{l}0.650^{* * *} \\
(0.064)\end{array}$ & $\begin{array}{l}0.251^{\star * *} \\
(0.048)\end{array}$ & $\begin{array}{l}0.393^{\star * *} \\
(0.080)\end{array}$ & $\begin{array}{l}0.252^{\star * *} \\
(0.069)\end{array}$ \\
\hline Size of the Council & $\begin{array}{l}0.129^{\star \star \star} \\
(0.015)\end{array}$ & $\begin{array}{l}0.062^{\star * \star} \\
(0.004)\end{array}$ & $\begin{array}{l}0.146^{\star * *} \\
(0.017)\end{array}$ & $\begin{array}{l}0.061^{\star \star \star} \\
(0.004)\end{array}$ \\
\hline White with Bachelors Degree & $\begin{array}{l}-0.334 \\
(0.231)\end{array}$ & $\begin{array}{l}-0.062 \\
(0.180)\end{array}$ & $\begin{array}{c}0.063 \\
(0.259)\end{array}$ & $\begin{array}{c}0.175 \\
(0.257)\end{array}$ \\
\hline Predominantly White City & $\begin{array}{l}-0.180^{\star} \\
(0.083)\end{array}$ & $\begin{array}{l}-0.242^{\star * *} \\
(0.058)\end{array}$ & $\begin{array}{c}0.128 \\
(0.084)\end{array}$ & $\begin{array}{l}-0.356^{\star * *} \\
(0.085)\end{array}$ \\
\hline Black Employment & $\begin{array}{l}-0.106 \\
(0.144)\end{array}$ & $\begin{array}{c}0.215 \\
(0.205)\end{array}$ & $\begin{array}{l}-0.102 \\
(0.173)\end{array}$ & $\begin{array}{c}0.031 \\
(0.299)\end{array}$ \\
\hline City Size (Logged) & $\begin{array}{l}0.214^{\star * \star} \\
(0.023)\end{array}$ & $\begin{array}{l}0.182^{\star * *} \\
(0.016)\end{array}$ & $\begin{array}{l}0.210^{\star * *} \\
(0.023)\end{array}$ & $\begin{array}{l}0.150^{\star * *} \\
(0.017)\end{array}$ \\
\hline 1986 & $\begin{array}{l}0.241^{\star *} \\
(0.082)\end{array}$ & $\begin{array}{l}0.225^{\star *} \\
(0.072)\end{array}$ & $\begin{array}{c}0.172 \\
(0.099)\end{array}$ & $\begin{array}{c}0.085 \\
(0.096)\end{array}$ \\
\hline 1991 & $\begin{array}{l}0.321^{\star * \star} \\
(0.091)\end{array}$ & $\begin{array}{l}0.321^{\star * *} \\
(0.076)\end{array}$ & $\begin{array}{c}0.214 \\
(0.112)\end{array}$ & $\begin{array}{c}0.140 \\
(0.112)\end{array}$ \\
\hline 1996 & $\begin{array}{l}0.412^{\star * *} \\
(0.089)\end{array}$ & $\begin{array}{l}0.209^{\star *} \\
(0.070)\end{array}$ & $\begin{array}{c}0.239^{*} \\
(0.107)\end{array}$ & $\begin{array}{c}0.042 \\
(0.094)\end{array}$ \\
\hline 2001 & $\begin{array}{l}0.406^{\star * *} \\
(0.092)\end{array}$ & $\begin{array}{l}0.298^{\star * *} \\
(0.072)\end{array}$ & $\begin{array}{l}0.290^{\star *} \\
(0.110)\end{array}$ & $\begin{array}{c}0.148 \\
(0.098)\end{array}$ \\
\hline 2006 & $\begin{array}{l}0.400^{* * *} \\
(0.089)\end{array}$ & $\begin{array}{l}0.359^{* * *} \\
(0.071)\end{array}$ & $\begin{array}{l}0.319^{\star *} \\
(0.105)\end{array}$ & $\begin{array}{c}0.230^{*} \\
(0.094)\end{array}$ \\
\hline Section $5 *$ BlackVAP & & & $\begin{array}{l}-1.843^{* * *} \\
(0.551)\end{array}$ & $\begin{array}{l}-0.076 \\
(0.171)\end{array}$ \\
\hline Section $5 *$ SMD & & & $\begin{array}{l}0.975^{\star * *} \\
(0.174)\end{array}$ & $\begin{array}{c}0.118 \\
(0.098)\end{array}$ \\
\hline Section $5 *$ Mixed & & & $\begin{array}{l}0.747^{\star * *} \\
(0.138)\end{array}$ & $\begin{array}{l}-0.028 \\
(0.097)\end{array}$ \\
\hline Section $5 *$ Council Size & & & $\begin{array}{c}0.026 \\
(0.041)\end{array}$ & $\begin{array}{l}0.077^{\star * *} \\
(0.011)\end{array}$ \\
\hline Section $5+$ White BA & & & $\begin{array}{l}-1.741^{\star *} \\
(0.544)\end{array}$ & $\begin{array}{l}-0.677 \\
(0.370)\end{array}$ \\
\hline Section $5 *$ Black Employment & & & $\begin{array}{l}-0.042 \\
(0.314)\end{array}$ & $\begin{array}{c}0.215 \\
(0.414)\end{array}$ \\
\hline Section $5 * 1986$ & & & $\begin{array}{c}0.183 \\
(0.177)\end{array}$ & $\begin{array}{c}0.333^{\star} \\
(0.147)\end{array}$ \\
\hline Section $5 * 1991$ & & & $\begin{array}{c}0.250 \\
(0.194)\end{array}$ & $\begin{array}{c}0.374^{\star} \\
(0.159)\end{array}$ \\
\hline Section $5 * 1996$ & & & $\begin{array}{l}0.495^{\star *} \\
(0.191)\end{array}$ & $\begin{array}{l}0.465^{\star *} \\
(0.146)\end{array}$ \\
\hline Section $5 * 2001$ & & & $\begin{array}{c}0.355 \\
(0.198)\end{array}$ & $\begin{array}{l}0.396^{\star *} \\
(0.150)\end{array}$ \\
\hline
\end{tabular}




\begin{tabular}{|c|c|c|c|c|}
\hline & \multicolumn{2}{|c|}{ Baseline Model } & \multicolumn{2}{|c|}{ Full Model } \\
\hline & Logit & $\begin{array}{c}\text { Zero-Truncated } \\
\text { Poisson }\end{array}$ & Logit & $\begin{array}{c}\text { Zero-Truncated } \\
\text { Poisson }\end{array}$ \\
\hline & beta/standard error & $\begin{array}{c}\text { beta/standard } \\
\text { error }\end{array}$ & $\begin{array}{c}\text { beta/standard } \\
\text { error }\end{array}$ & $\begin{array}{c}\text { beta/standard } \\
\text { error }\end{array}$ \\
\hline Section $5 * 2006$ & & & $\begin{array}{c}0.247 \\
(0.198)\end{array}$ & $\begin{array}{c}0.373^{\star} \\
(0.147)\end{array}$ \\
\hline Constant & $\begin{array}{l}-5.293^{\star * *} \\
(0.265)\end{array}$ & $\begin{array}{l}-3.909^{* * *} \\
(0.247)\end{array}$ & $\begin{array}{l}-5.376^{\star * \star} \\
(0.287)\end{array}$ & $\begin{array}{l}-3.321^{\star * *} \\
(0.313)\end{array}$ \\
\hline $\mathrm{N}$ & 11096 & 3816 & 11096 & 3816 \\
\hline chi2 & 4496.241 & 3525.322 & 4584.946 & 3579.009 \\
\hline aic & 10443.400 & 6111.761 & 10376.695 & 6080.074 \\
\hline bic & 10553.115 & 6205.465 & 10566.868 & 6242.495 \\
\hline
\end{tabular}

${ }^{*} p<0.05,{ }^{* *} p<0.01,{ }^{* *} p<0.001$.

movement towards representational parity in black representation.

Last, we address the most complicated question: how did the VRA make a difference? Based on our review of the literature on black representation, we identified several ways in which Section 5 coverage might condition the effects of traditional explanatory factors. The first of these focused on racialized voting and posited that the size of the black voting-age population would have a greater impact in covered jurisdictions. Turning to the results from our conditional model (Section $5^{*}$ Black VAP), we do not find support for this expectation. In fact, the results suggest that Section 5 reduces the effect of black population size in covered jurisdictions in the first stage of representation and has no effect in the second stage. These findings corroborate the patterns witnessed in Figure 2. For example, moving from $10 \%$ to $20 \%$, black VAP in an uncovered place raises the likelihood of any representation 0.284 , as opposed to 0.221 in covered places. At higher percentages of black VAP, however, these effects are diminished: moving from $40 \%$ to $50 \%$, VAP in an uncovered place increases the likelihood 0.037 in covered places and 0.035 in uncovered places. Together, these findings suggest that despite the infrastructure to combat voter disenfranchisement and mobilize voters, the legacy of intimidation and white resistance negatively impacted the ability of blacks to capitalize on voter strength, particularly in places where black voter strength was low.

We next examine the effects of electoral structures. Recall that the literature has consistently found that SMDs and larger council sizes lead to greater black representation. Taking the context of coverage into consideration, we expected that these effects would be stronger in covered jurisdictions because it is in these jurisdictions where black voters should have greater political agency to utilize these structures to translate their votes to seats. The results in Table 1 support this expectation. Specifically, we find positive and significant coefficients on each of the three interaction terms for Section 5 and electoral arrangements (SMD, Mixed, and Council Size). One way to illustrate these relationships might be via the concept of the "population threshold"-measuring the black population size at the point where the probability of at least one black councilor is greater than $50 \%$-and that is precisely what we do in Figure 3. Comparing estimates of this threshold across the three electoral structures for covered and uncovered jurisdictions and over time essentially allows us to compare the efficacy of different electoral arrangements at translating black population to seats. In particular, for any given panel year, the black population threshold is lower in a covered city than in an uncovered city for all three electoral structures, and the greatest differences are found in SMD and Mixed systems. We also examined how this relationship has changed over time. In uncovered cities, the threshold has remained almost constant between 1981 and 2006. In contrast, covered cities have experienced a declining threshold over time across all three electoral structures. Thus, in cities covered by Section 5, crossing the population threshold has become more likely at lower black population values over time, and these effects are largest for SMD and Mixed systems.

The results in Table 1 show the conditional effects on electoral structure are limited to the first stage of 


\section{Figure 3 Estimated Percent Black VAP Thresholds for Electing at Least One Black Councilor (by year, Section 5 coverage, and Black VAP \%)}
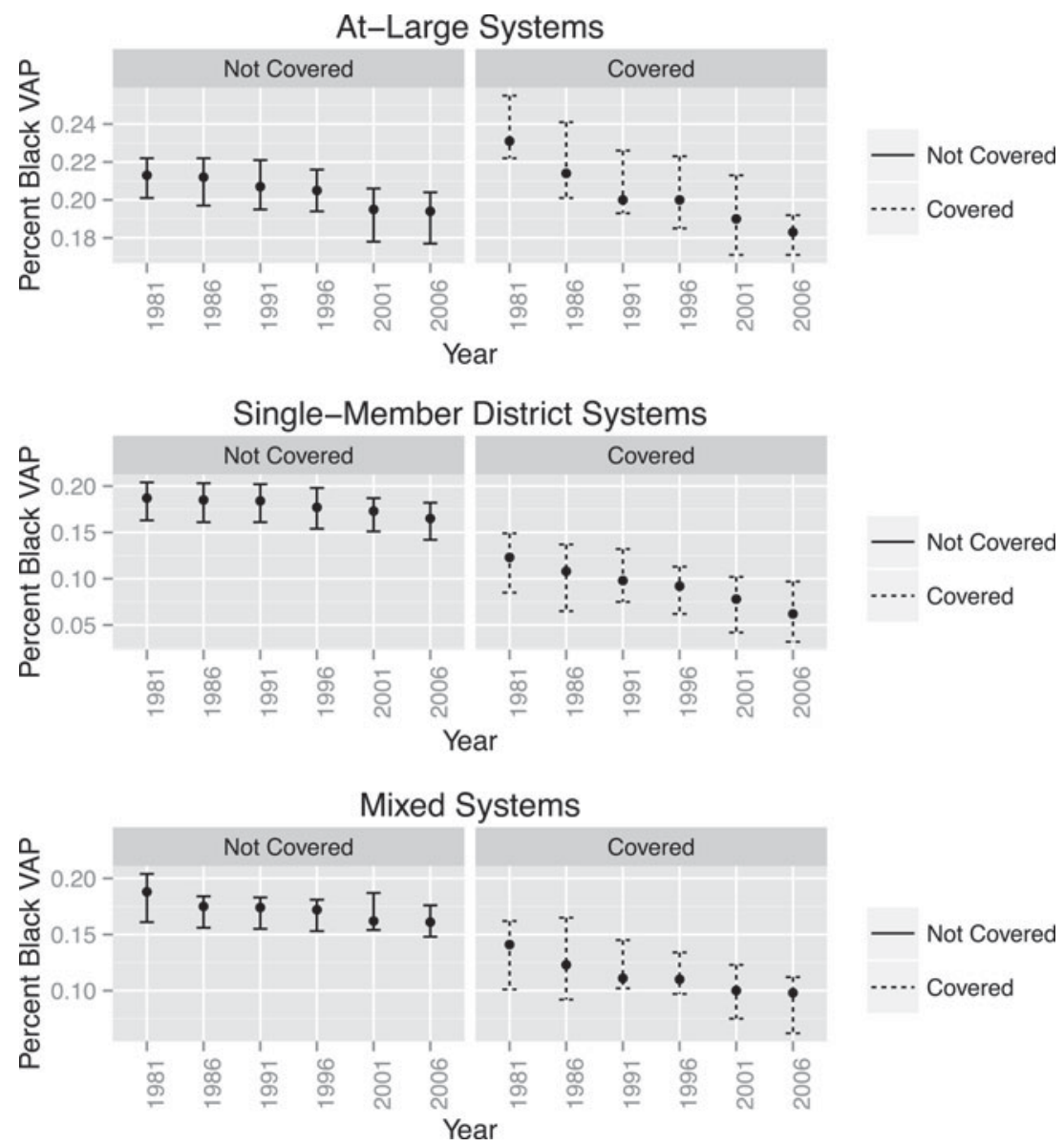

Note: Estimated black voting-age population at which the likelihood of electing at least one black councilor is greater than $50 \%$, and $95 \%$ confidence intervals are displayed by electoral type. See text for additional details.

representation. In contrast, the conditional effects of council size occur after the hurdle has been crossed. Much like the negative sign on the Section $5 *$ Black $V A P$ variable discussed earlier, however, what we find is a decrease in the effect of council size on the expected number of black councilors. For example, the predicted number of black councilors in covered SMD cities goes from 1.16 to 1.31 (a 0.15 increase) as we move from a five-person to a seven-person city council, compared to 1.04 to 1.25 (a 0.21 increase) in uncovered cities. ${ }^{13}$ Yet, as this example illustrates, covered jurisdictions still have a greater expected number of councilors overall. Thus, while the mechanism by which larger legislative bodies provide more opportunities for representation seem to make a larger difference in the likelihood of representation

\footnotetext{
${ }^{13}$ Black VAP set to in-sample mean $(=20 \%)$; year $=2001$, and all other covariates at their mean/modal values.
}

in uncovered cities, covered cities still have a greater extent of representation.

The third conditional relationship we set out to test focused on economic resources. Building on historical accounts of documented economic intimidation, we inferred that Section 5 might reduce the effect of black resources on black representation, thus producing a negative coefficient on the Section $5^{*}$ Black Employment interaction term. The results in Table 1, however, are null: when controlling for other factors, there is no difference in the effect of black resources across covered and noncovered jurisdictions. In fact, the results from the baseline model (columns 1 and 2) indicate that regardless of the context of coverage, the percent of black employment in the city plays no role in the likelihood of any black representation or the extent of black representation.

Finally, we also set out to test the possibility that Section 5 might condition the effect of white crossover 
voting. As we noted, taking the context of Section 5 coverage into consideration, we suspect that racial threat and prejudice, rather than intergroup cooperation, may more accurately describe the nature of local electoral politics in covered jurisdictions. Controlling for the possibility that it may be that it is the overall white population that is detrimental to black representation, the findings in Table 1 (Section $5^{*}$ White $B A$ ) are supportive of the racial threat claim. The negative coefficient on the interaction term indicates that cities with a larger concentration of educated whites (our proxy for liberal white voters) are less likely to have any black council representation when they are located in areas covered by Section 5 than those not covered by Section 5 . Indeed, a one standard deviation increase in the White BA population (moving from $20 \%$ to $30 \%$ ) decreases the likelihood of black council representation 0.032 in covered jurisdictions. In uncovered jurisdiction, we find a smaller decrease (0.021).

\section{Conclusions and Implications for Further Research}

The temporary nature of Section 5 of the Voting Rights Act signaled optimism in the outcome of the legislation: perhaps within a short period of time, the effects of long-standing disenfranchisement practices would be righted, and the need for federal oversight on state and local voting practices would be moot. Unfortunately, testimony from the 2006 reauthorization hearings dispelled this hopeful sentiment as numerous lawmakers and scholars documented the continued attempts of state and local jurisdictions to create institutional structures that dilute minority voting strength, and consequently, pose barriers to minority representation. In this study, we contribute to the ongoing dialogue regarding the relevancy of the VRA by systematically studying how the landmark legislation has, to influenced black municipal representation and continuous to do so. In answering the question motivating our work - Are we there yet? The answer is no. However, in this study, we have not only demonstrated that the VRA continues to be a significant force in ensuring gains in black representation, but it also provided evidence about how the VRA has contributed to these over-time gains. Below, we highlight the major contributions of this study and conclude with suggestions for future research.

First, the evidence presented here supports continued efforts to reauthorize the Voting Rights Act.
As our analysis shows, ceteris paribus, Section 5 coverage leads to greater breadth of black representation on city councils. In particular, the number of cities that have crossed the representational hurdle and elected a black member to their city council has increased precipitously under Section 5 coverage. While gains have also been made in cities not covered by Section 5, they have occurred at a decidedly slower pace.

Second, our findings unpack the mechanisms by which the VRA might impact minority representation. Specifically, we find evidence that coverage leads to an amplification of the effects of minority voting strength, council size, and electoral structures. Thus, whereas other research has demonstrated that each of these factors are important for minorities seeking elected seats, our findings suggest the coverage reduces the hurdles posed by smaller black voting populations, smaller legislative councils, and at-large or mixed electoral systems. Further, our alternative analytic strategy allowed us to examine differences in how electoral structure, population size, and coverage impact the likelihood of any representation versus the extent of representation and thus offered additional leverage in understanding these relationships.

Finally, examining the conditional effects of time highlight some important temporal shifts in how the VRA impacts representation. For one, the results presented in Figure 3 demonstrate that the black-population thresholds required to elect black councilors have decreased over time: smaller black voting-age populations are required to cross the hurdle of representation in cities covered by Section 5 . Whether these changes stem from decreasing racial bias in the electorate, an increase in the number of black candidates seeking council seats, a closing of the blacknonblack registration/turnout gap, or some combination of all three, is a question that cannot be answered with the data at hand. Moreover, our findings do provide an empirical foundation with which to address the question of when the VRA has mattered. In examining a 25-year period, our research confirms that the direct and indirect influences of the VRA continues to be felt in covered jurisdictions and can explain much of the electoral success blacks have witnessed in municipal elections, particularly in the second stage of representation. Based on the present study, we can conclude that Section 5 coverage afforded under the aegis of the VRA has paid dividends to racial minorities that otherwise might not have resulted. This was precisely the argument that echoed the loudest in Congressional deliberations of VRA reauthorization in 2006.

Even as this study makes important contributions to the extant literature, it also raises a number of 
additional questions. The first is the relationship between the VRA and the language of minorities, particularly Latinos. As we noted early on, the 1975 amendments to the VRA extend Section 5 coverage to a number of places with large Latino populations. In addition, the 1975 amendments included provisions to address the structural barriers to participation for language minority groups (Sections 203 and 4(f)4). Following expectations set by the positive impact of Section 5 coverage on black representation, a few early pieces investigated these effects for Latinos (Brischetto et al 1994; Garcia 1986) but found lukewarm results. Although empirical analysis of the relationship of Sections 203 and 4(f)(4) to Latino representation have not yet been conducted, language-assistance coverage may indirectly lead to greater Latino political incorporation as well. What is unknown, however, is whether the mechanisms by which the VRA impacts Latino representation mirrors that for blacks or whether these differ in significant ways.

The second question centers on the relationship between the VRA and minority-candidate emergence. That is, all extant work on local minority representation focuses on the winners of elections but cannot speak to the ways in which demographics and institutional features of a city (including VRA coverage) impact the likelihood of a minority candidate running for office. This question of the supply of minority candidates is particularly salient in a discussion of the effects of the VRA, given the explicit goal of the Act to ensure minority representation in elected office. When do minority candidates run for office? How does the local political, demographic, and socioeconomic context shape the likelihood of winning? And what impact does the VRA have on this minority-candidate emergence and success?

Finally, the onslaught of Department of Justice investigations into voter ID laws in 2012 suggest that the most salient threats to minority voting rights and representation have in many ways evolved beyond what the Act was originally intended to address. As Persily notes: "disenfranchisement of felons, the discriminatory application of voter ID laws, and partisan or incompetent administration of elections present greater nationwide challenges to minority voting rights than the voting changes ordinarily denied preclearance in the covered jurisdictions $(2007,178)$. How these laws impact minority representation, however, have not been addressed, and thus the question remains as to how other provisions under the VRA may protect gains in minority representation and ensure future minority success as we strive to "get there."

\section{References}

Alozie, Nicholas O., and Lynne L. Manganaro. 1993. "Black and Hispanic Council Representation: Does Council Size Matter?" 29 (December): 276-98.

Andrews, Kenneth. 2004. Freedom is a Constant Struggle. Chicago: University of Chicago Press.

Andrews, Kenneth T. 1997. "The Impacts of Social Movements on the Political Process: The Civil Rights Movement and Black Electoral Politics in Mississippi." American Sociological Review 62 (5): 800-19.

Brischetto, Robert, David Richards, Chandler Davidson, and Bernard Grofman. 1994. "Texas". In Quiet Revolution in the South, ed. Chandler Davidson and Bernard Grofman. Princeton, NJ: Princeton University Press, 233-70.

Browning, Rufus, Dale R. Marshall, and David Tabb. 1984. Protest is Not Enough: The Struggle of Blacks and Hispanics for Equality in Urban Politics. Los Angeles: University of California Press.

Bullock, Charles S., III and Bruce A. Campbell. 1984. "Racist or Racial Voting in the 1981 Atlanta Municipal Elections." Urban Affairs Quarterly 20: 149-64.

Bullock, Charles S., III, and Susan A. MacManus. 1993. “Testing Assumptions of the Totality-of-the-Circumstances Test: An Analysis of the Impact of Structures on Black Descriptive Representation.” American Politics Quarterly 21: 290-306.

Canon, David. 2008. "Renewing the Voting Rights Act: Retrogression, Influence, and the "Georgia v. Ashcroft Fix"." Election Law Journal 7 (1): 3-24.

Davidson, Chandler, and George Korbel. 1981. "At-Large Elections and Minority-Group Representation: A Re-Examination of Historical and Contemporary Evidence." Journal of Politics 43 (4): 982-1005.

Engstrom, Richard L., and Michael D. McDonald. 1981. "The Election of Blacks to City Councils: Clarifying the Impact of Electoral Arrangements on the Seats/Population Relationship." American Political Science Review 75 (2): 344-54.

Garcia, John A. 1986. "The Voting Rights Act and Hispanic Political Representation in the Southwest." Publius 16 (4): 49-66.

Giles, Michael W., and Arthur S. Evans. 1985. "External Threat, Perceived Threat, and Group Identity." Social Science Quarterly 66: 50-66.

Grofman, Bernard, and Chandler Davidson. 1994. "The Effect of Municipal Election Structure on Black Representation in Eight Southern States." In Quiet Revolution in the South, ed. Chandler Davidson and Bernard Grofman. Princeton, NJ: Princeton University Press, 301-34.

Grofman, Bernard, and Lis Handley. 1995. "1990s Issues in Voting Rights.” Mississippi Law Journal 65 (2): 205-70.

Hunt, Matthew O., and George Wilson. 2011. "Introduction: Race, Racial Attitudes, and Stratification Beliefs: Evolving Directions for Research and Policy." ANNALS of the American Academy of Political and Social Science 634: 6-15.

Joint Center for Political and Economic Studies. Various years. National Roster of Black Elected Officials. Washington, DC: Joint Center for Political and Economic Studies.

Jones, Clinton. 1976. "The Impact of Local Election Systems on Black Representation." UrbanAffairs Review 11: 345-356.

Karnig, Albert K., and Susan Welch. 1980. Black Representation and Urban Policy. Chicago: University of Chicago Press. 
Liu, Baodong. 2001. "Racial Contexts and White Interests: Beyond Black Threat and Racial Tolerance." Political Behavior 23 (2): 157-80.

Marschall, Melissa J., Anirudh V. S. Ruhil, and Paru R. Shah. 2010. "The New Racial Calculus: Electoral Institutions and Black Representation in Local Legislatures." American Journal of Political Science 54 (1): 107-24.

McAdam, Doug. 1982. Political Process and the Development of Black Insurgency. University of Chicago Press.

Meier, Kenneth J., and Joseph Stewart. 1991. "Cooperation and Conflict in Multiracial School Districts." The Journal of Politics 53 (4): 1123-1133.

Meier, Kenneth J., and Robert E. England. 1984. "Black Representation and Educational Policy: Are They Related?” American Political Science Review 78 (2): 392-403.

Morrison, Minion. 1987. Black Political Mobilization: Leadership, Power, and Mass Behavior. State University of New York Press.

Mundt, Robert J., and Peggy Heilig. 1982. "District Representation: Demands and Effects in the Urban South." Journal of Politics 44 (4): 1035-1048.

National Assocation of Latino Elected Officials. Various Years. National Directory of Latino Election Officials. Los Angeles, CA: National Association of Latino Election Officials.

Newport, Frank. 2008. "Americans See Obama Election as Race Relations Milestone.”http://www.gallup.com/poll/111817/ americans-see-obama-election-race-relations-milestone.aspx

Parker, Frank. 1990. Black Votes Count. Chapel Hell: University of North Carolina Press.

Persily, Nathaniel. 2007. "The Promise and Pitfalls of the New Voting Rights Act." Yale Law Journal 117: 174-253.

Salamon, Lester M., and Stephen Van Evera. 1973. "Fear, Apathy, and Discrimination: A Test of Three Explanations of Political
Participation." The American Political Science Review 67 (4): 1288-1306.

Sass, Tim R., and Bobby J. Pittman. 2000. "The Changing Impact of Electoral Structure on Black Representation in the South, 1970-1996." Public Choice 104 (3-4): 369-88.

Taebel, Delbert. 1978. "Minority Representation in City Councils: The Impact of Structure on Blacks and Hispanics." Social Science Quarterly 59 (June): 142-45.

Thompson, Kenneth. 1982. The Voting Rights Act and Black Electoral Participation. Washington DC: Joint Center for Political and Economic Studies.

Trounstine, Jessica L., and Melody E. Valdini. 2008. "The Context Matters: The Effects of Single-Member versus At-Large Districts on City Council Diversity." American Journal of Political Science 52 (3): 554-69.

Tucker, James T. 2007. "The Politics of Persuasion: Passage of the Voting Rights Reauthorization Act of 2006." Notre Dame Journal of Legislation 33: 205-67.

Paru Shah is an Assistant Professor at the University of Wisconsin-Milwaukee, Milwaukee, WI 53201.

Melissa J. Marschall is the Albert Thomas Associate Professor at Rice University, Houston, TX 77005.

Anirudh V. S. Ruhil is an Associate Professor at Ohio University and the Associate Director of Research and Graduate Programs, Athens, $\mathrm{OH} 45701$ 